\title{
Investigation of Behaviour Styles of the Coaches of Athletes Who Competed at 2018 Snowboard Cross World Cup
}

\author{
Mehmet Gül ${ }^{1, *}$, M. Ceyhun Birinci' ${ }^{2}$, S. Ahmet Ăgaoğlu ${ }^{2}$ \\ ${ }^{1}$ Department of Sport Management, School of Physical Education and Sports, Sivas Cumhuriyet University, Sivas, Turkey \\ ${ }^{2}$ Department of Training Education, Faculty of Yaşar Doğu Sport Science, Ondokuz Mayıs University, Samsun, Turkey
}

Copyright $\bigcirc 2019$ by authors, all rights reserved. Authors agree that this article remains permanently open access under the terms of the Creative Commons Attribution License 4.0 International License

\begin{abstract}
Coaches are one of the leading people who have a role in athletes' success. Physical and physiological characteristics of many elite athletes are close to each other. The most important psychological factor as the distinguishing element bringing success is the coaches' behavioral approaches to their athletes. It is important to find out the behavioural styles of the coaches of athletes who are representing their countries in international organizations and who are showing top level performance in increasing their countries' success. In this sense, the purpose of this study is to analyze the coaching behaviour styles of the coaches of snowboard cross athletes representing their countries in the world cup. The study is a descriptive study in the model of survey. 3-item personal information form developed by the researcher and Coaching Behaviour Scale for Sport- CBS-S consisting of 7 factors and 47 items were used as data collection tool. The scale was given to 68 of 97 athletes competing for different countries in Snowboard Cross World Cup that was held in Erzurum/ Turkey in January 2018. Percentage, frequency, mean and average values were used in the analysis of data. Various difference tests were used to find out the differences between variables. 24 female and 44 male athletes participated in the study. Average age of the athletes was found as $25,16 \pm 4,53$. No significant difference was found in terms of the variables of age, gender and the continent athletes participated from and it was found that athletes assessed the positive behavioural styles of coaches in very high levels $(6,98 \pm 1,21)$, while they assessed their negative coaching behaviours in very low levels $(1,08 \pm 0,14)$. According to the results obtained, it is recommended for behavioural styles of coaches assessed within the context of similar researches to be applied to other sport branches.
\end{abstract}

Keywords Coach, Behaviour, Coaching Behaviour, Athlete, Snowboard, World Cup

\section{Introduction}

It can be seen that training programs prepared recently in the sport world for athletes' physical and physiological development are similar to each other. Many countries prepare their athletes to competitions with similar training programs.

It can be seen that motivation is the distinguishing factor in equivalent strength and physiological performances. The influence of the behaviours of athletes deals with stand out as the leading most important factor influencing motivation. The leading and most important of these people are coaches as the people who spend the most time with athletes (Gül and Others 2015).

As agreed by many sports people, it is not enough only to have top level of physical and physiological parameters to be an athlete. Athletes should be able to deal with pressures they come across, adapt to changing conditions and rules, have discipline to show good performance and maintain their concentration (Konter, 1996). They need the help of a coach to be able to succeed all these. For this reason, coaches' skills related with their task have a very important influence on their performance (Horn, 2008; Weiss et al., 2008). One of the most important duties of coaches is to show behaviours to increase the athletes' motivation. In terms of the coach, leadership is the most important factor to lead the athletes and to show ability at the point of guiding them (İkizler, 2000).

Coaches are considered as leaders in the centre of sports world (Lyle, 1993; Abraham and Collins, 1998). Coaches have a very important place in the development of sport and athletes. Most of the qualifications that an athlete gains are determined by the coach. The interaction between the coach and the athletes has always been considered as a factor that determines performance (Serpa, 1999). Coaches are people who have the most important place in increasing an athlete's success and quality in sportive life (Williams et al., 2003). 
Analyzing coaching behaviours and finding out how they use coaching skills they apply while training an athlete will enable to see the way they follow for sportive success (More and Franks, 1996). A great number of studies conducted express that the most important formula of sportive success is hidden in coaching behaviour (Vargas et al, 2003). Assessment of coaching behaviour is important in terms of assessing athlete-coach relationship and guiding this relationship positively (Cote et al, 1999). Thus, coaching behaviour styles are very important in the success of athletes in snowboarding which is among high risk sports category and which requires a high level of performance. Based on these, the purpose of this study is to analyze the behaviour styles of the coaches of athletes who participated in Snowboard Cross World Cup.

\section{Material and Method}

The research was prepared by using survey method within the context of descriptive research methods. Descriptive research is a method, which describes and explains what already exists and what takes place without an intervention of the researcher to the case (Sönmez and Alacapınar, 2013).

\subsection{Data Collection Tools}

In the study, a 3-item demographic information form to find out the age, gender and countries of the participants (athletes) and Coaching Behaviour Scale for Sport- CBS-S consisting of 7 factors and 47 expressions developed by Mallet and Cote were used. Coaching Behaviour Scale for Sport- CBS-S is prepared as 7-Likert type ( $7=$ Always, $6=$ very often, $5=$ often, $4=$ fairly often, $3=$ sometimes, $2=$ rarely, $1=$ never) and 7 factors (physical training and planning, technical skills, mental preparation, goal setting, competition strategies, personal rapport and negative personal rapport). The scale is scored according to average value. The smallest average value that can be taken from a scale is 1 , while the highest value is 7 .

The CBS-S is an survey that assesses respondent's perceptions of coaches' roles in athletes' development technical skills, mental preparation, goal setting, competition strategies, physical training and planning, as well as positive and negative personal rapport held between the athletes and their coaches (Gould, Carson, 2010). The survey Cronbach's alphas value was evaluated in 0,815

For the majority of athletes involved in sport, the coach is an influential element of the competitive experience. Therefore, there are seven coaching behaviours (physical training, mental preparation, goal setting, technical skills, competition strategies, personal rapport and negative personal rapport) effect on the athletes' performance (Baker at al., 2000). In this way, the survey answers the purpose of the research.

\subsection{Data Collection Tool}

In the study, the scale was used in its original form. A total of 97 athletes participated in 2018 Snowboard cross World Cup organized in Erzurum/Turkey between 19 and 21 January 2018. Of the 97 athletes, 68 athletes were chosen through random sampling method by taking their levels of English into consideration and the scale was applied on these athletes. During the application of the scale, care was taken for the athletes to understand the expressions clearly and to fill in the scale, which described coaches' behavioural styles without being under any pressure.

\subsection{Data Analysis}

The data obtained were analyzed with IBM SPSS STATISTICS 25 program. In order to ease the assessment of data, ages and countries of the athletes were grouped. The data were presented as percentage, frequency, mean, average and standard deviation values. In order to find out the differences between various variables (age, gender, continent) Kolmogorov Smirnov Test was conducted first to find out whether the data were normally distributed. As a result of the test, Kruskal Wallis and Mann Withney- U tests were used to test the differences between variables which were not normally distributed.

\section{Results}

According to the results of the study, 65 of the participants were male, while 35 were female and their average age was $25,16 \pm 4,53$.

On the other hand, the country distribution of the athletes who participated in the study are presented in Table 1.

Table 1. Distribution of the athletes who participated in the study in terms of countries

\begin{tabular}{ccc}
\hline Countries & f & Percentage \% \\
\hline Austria & 11 & 16,2 \\
\hline Canada & 11 & 16,2 \\
\hline Spain & 3 & 4,4 \\
\hline Finland & 1 & 1,5 \\
\hline France & 10 & 14,7 \\
\hline Germany & 5 & 7,4 \\
\hline Italy & 7 & 10,3 \\
\hline Japan & 2 & 2,9 \\
\hline Norway & 1 & 1,5 \\
\hline Poland & 2 & 2,9 \\
\hline Russia & 2 & 2,9 \\
\hline Switzerland & 2 & 2,9 \\
\hline USA & 11 & 16,2 \\
\hline Total & 68 & 100 \\
\hline
\end{tabular}


When Table 1 is reviewed, it can be seen that the highest number of participation was in athletes from Austria, Canada and USA ( $\mathrm{f}=11,16,2 \%$ ), while on the other hand the lowest number of participation was in athletes from Finland and Norway ( $\mathrm{f}=1,1,5 \%)$

The distribution of the countries of athletes in terms of continents is shown in Table 2.

Table 2. Distribution of the athletes who participated in the study in terms of continent

\begin{tabular}{ccc}
\hline Continent & f & Percentage $\%$ \\
\hline Europe & 42 & 61,8 \\
\hline Asia & 4 & 5,9 \\
\hline America & 22 & 32,4 \\
\hline Total & 68 & 100 \\
\hline
\end{tabular}

According to Table 2, in the regional distribution of the athletes who participated in the study, it can be seen that there were athletes from 3 continents. In this context, it was found that the highest number of athletes were from $(\mathrm{f}=42$, $61,8 \%$ ) Europe, while the lowest number of athletes were from $(\mathrm{f}=4,5,9 \%)$ Asia.

The general assessments of the athletes about the behavioural styles of their coaches are given in Table 3 .

Table 3. Coaching behaviour styles of athletes who participated in the study

\begin{tabular}{lcc}
\hline \multicolumn{1}{c}{ Coaching Behaviour Scale for Sport- CBS-S } & Ave. & S.D. \\
\hline Physical training and planning & 6,99 & 0,03 \\
\hline Technical skills & 6,99 & 0,06 \\
\hline Mental preparation & 9,98 & 0,12 \\
\hline Goal setting & 6,96 & 0,17 \\
\hline Competition strategies & 6,98 & 0,12 \\
\hline Personal rapport & 6,89 & 0,24 \\
\hline Negative personal rapport & 1,08 & 0,14 \\
\hline
\end{tabular}

When Table 3 is examined, it can be seen that the athletes who participated in the study assessed the behaviours of their coaches positively.
Table 4 shows the results obtained as a result of difference tests conducted for the variable of gender.

Table 4. Comparison of the participants in terms of the variable of gender

\begin{tabular}{|c|c|c|c|c|}
\hline $\begin{array}{c}\text { Coaching } \\
\text { Behaviour Scale } \\
\text { for Sport- CBS-S }\end{array}$ & Gender & Ave. S.d. & $\begin{array}{c}\mathrm{P} \\
\text { value }\end{array}$ & $\begin{array}{c}\text { Mann- } \\
\text { Whitney U } \\
\text { value }\end{array}$ \\
\hline \multirow{2}{*}{$\begin{array}{l}\text { Physical training } \\
\text { and planning }\end{array}$} & Male & $6,99 \pm 0,01$ & \multirow{2}{*}{0,46} & \multirow{2}{*}{516} \\
\hline & Female & $7,00 \pm 0,00$ & & \\
\hline \multirow{2}{*}{ Technical skills } & Male & $6,99 \pm 0,01$ & \multirow{2}{*}{0,64} & \multirow{2}{*}{517,5} \\
\hline & Female & $6,97 \pm 0,10$ & & \\
\hline \multirow{2}{*}{$\begin{array}{c}\text { Mental } \\
\text { preparation }\end{array}$} & Male & $6,97 \pm 0,15$ & \multirow{2}{*}{0,46} & \multirow{2}{*}{516} \\
\hline & Female & $7,00 \pm 0,00$ & & \\
\hline \multirow{2}{*}{ Goal setting } & Male & $6,95 \pm 0,21$ & \multirow{2}{*}{0,91} & \multirow{2}{*}{525} \\
\hline & Female & $6,98 \pm 0,06$ & & \\
\hline \multirow{2}{*}{$\begin{array}{l}\text { Competition } \\
\text { strategies }\end{array}$} & Male & $6,97 \pm 0,15$ & \multirow{2}{*}{0,46} & \multirow{2}{*}{516} \\
\hline & Female & $7,00 \pm 0,00$ & & \\
\hline \multirow{2}{*}{ Personal rapport } & Male & $6,96 \pm 0,15$ & \multirow{2}{*}{0,00} & \multirow{2}{*}{318,5} \\
\hline & Female & $6,76 \pm 0,31$ & & \\
\hline \multirow{2}{*}{$\begin{array}{l}\text { Negative personal } \\
\text { rapport }\end{array}$} & Male & $1,07 \pm 0,13$ & \multirow{2}{*}{0,88} & \multirow{2}{*}{518,5} \\
\hline & Female & $1,09 \pm 0,15$ & & \\
\hline
\end{tabular}

When the participants' ways of perceiving coaches' behaviour styles were examined in terms of their gender, they were found to have similar perceptions, with differences in "personal rapport" factor. According to results, female athletes were found to have lower averages for their coaches' behaviour styles $(\boldsymbol{M}=\mathbf{6 , 9 6} \pm \mathbf{0 , 1 5}$, $F=6,76 \pm 0,31$ )

In order to compare the coaching behaviours of the athletes in the study in terms of the continents they were in, first Kolmogorov Smirnov test was used to find out whether the data were normally distributed and Kruskal Wallis $U$ test was applied on the data which were not normally distributed. According to the results, as can be seen in Table 5, it was found that the athletes showed differences in the last two factors of the scale.

Table 5. Analysis of the coaching behaviours in terms of the continents the athletes' countries are in

\begin{tabular}{|c|c|c|c|c|c|c|c|c|}
\hline \multicolumn{2}{|c|}{ Continent } & $\begin{array}{c}\text { Physical training and } \\
\text { planning }\end{array}$ & $\begin{array}{c}\text { Technical } \\
\text { skills }\end{array}$ & $\begin{array}{c}\text { Mental } \\
\text { Preparation }\end{array}$ & $\begin{array}{c}\text { Goal } \\
\text { setting }\end{array}$ & $\begin{array}{c}\text { Competition } \\
\text { strategies }\end{array}$ & $\begin{array}{c}\text { Personal } \\
\text { rapport }\end{array}$ & $\begin{array}{c}\text { Negative eprsonal } \\
\text { rapport }\end{array}$ \\
\hline \multirow{2}{*}{ Europe } & Ave. & 6,9932 & 6,9851 & 6,9762 & 6,9444 & 6,9762 & $\mathbf{6 , 8 4 1 3 *}$ & $\mathbf{1 , 0 8 3 3}^{*}$ \\
\cline { 2 - 10 } & S.d. &, 04409 &, 07907 &, 15430 &, 21984 &, 15430 &, $\mathbf{2 9 4 3 7}$ &, $\mathbf{1 2 5 5 1}^{*}$ \\
\hline \multirow{2}{*}{ Asia } & Ave. & 7,0000 & 7,0000 & 7,0000 & 7,0000 & 7,0000 & $\mathbf{6 , 8 7 5 0 *}$ & $\mathbf{1 , 4 3 7 5 *}^{*}$ \\
\cline { 2 - 10 } & S.d. &, 00000 &, 00000 &, 00000 &, 00000 &, 00000 & $\mathbf{, 1 5 9 5 7}$ &, $\mathbf{1 2 5 0 0}$ \\
\hline \multirow{2}{*}{ America } & Ave. & 7,0000 & 7,0000 & 7,0000 & 7,0000 & 7,0000 & $\mathbf{7 , 0 0 0 0}$ & $\mathbf{1 , 0 1 7 0}^{*}$ \\
\cline { 2 - 10 } & S.d. &, 00000 &, 00000 &, 00000 &, 00000 &, 00000 & $\mathbf{, 0 0 0 0 0 *}$ &, $\mathbf{0 4 3 9 1 *}$ \\
\hline
\end{tabular}

$* \mathrm{p}<0,05$ 


\section{Discussion}

The purpose of the study is analysing of coaching behaviour of athletes who competed in 2018 Snowboard World Cup was hold in Samsun/ Turkey. From this point of view in this study, it was found that $65 \%$ of the participants coming from a total of 13 countries were male, while $35 \%$ were female and their average age was $25,16 \pm 4,53$. In a similar study conducted by Carlsson and Lundqvist (2016) in Sweden, $52 \%$ of the participants were male, while $48 \%$ were female and the average age of the group was 22,20 . In a study conducted by Baker et al. (2003) with participants from 14 different branches, $51 \%$ of the participants were male and $49 \%$ were female and the average age was 17,8 . In another study conducted by Baker et al. (1999) with 205 participants from 7 different branches, $47 \%$ of the participants were male and 53\% were female. In another study conducted by Baker et al. (2000) with 228 athletes from 15 different branches, $46 \%$ of the participants were female, while $54 \%$ were male and the average age of the participants was 18,3 . In a study conducted by Koh et al. (2014) on young athletes from Singapore, $75 \%$ of the athletes were male, while $25 \%$ were female. We believe that the difference between our study and the studies in literature in terms of age and percentage of participants' results from the fact that the study was conducted on athletes in the finals of 2018 Snowboard cross World Cup and this caused differences in numbers and percentages.

In this study, when the factors of Coaching Behaviour Scale for Sport- CBS-S were examined, it was found that the athletes who participated in the study assessed their coaches' behaviours positively. Baker et al. (1999) stated that there were moderately significant correlations between positive factors. Baker et al. (2000) mentioned a correlation between low and moderate ranges. In addition, they found high correlations for goal setting and competition strategies and mental preparation and they stated that these correlations were the indicators of a high association between variables that can depend on overlaps.

Baker et al. (2003) found significant correlations between coaching behaviours as a result of the overlapping between these factors. However, they stated that the amount of variance explained was between 55 and $58 \%$ for three pairs of variables (goal setting-mental preparation, competition strategies-mental preparation and competition strategies-technical skills).

Koh et al. (2014) stated that the lowest average scores came from negative personal rapport factor, while the highest average scores came from technical skills factor.

It can be seen that this study has similar results with the other studies conducted. According to the results we got from the participants, we believe that the reason for positivity in the factors of Coaching Behaviour Scale for Sport resulted from the fact that the study was conducted on athletes who participated in Snowboard Cross World Cup final and that the athletes and coaches in this level are very well equipped.

\section{REFERENCES}

[1] Abraham, A., \& Collins, D. (1998). Examining and extending research in coach development. Quest, 50(1), 59-79.

[2] Baker, J., Yardley, J., \& Cote, J. (2003). Coach Behaviors and Athlete Satisfaction in Team and Individual Sports. International Journal of Sport Psychology, 34, 226-239.

[3] Baker, J., Côté, J., \& Hawes, R. (2000). The relationship between coaching behaviours and sport anxiety in athletes. Journal of science and medicine in sport, 3(2), 110-119.

[4] Carlsson, A., \& Lundqvist, C. (2016). The Coaching Behavior Scale for S port (CBS - S): A psychometric evaluation of the Swedish version. Scandinavian journal of medicine \& science in sports, 26(1), 116-123.

[5] Cote, J., Yardley, J., Hay, J., Sedgwick, W., \& Baker, J. (1999). An exploratory examination of the coaching behavior scale for sport. Avante, 5(3), 82-92.

[6] Côté, J., \& Sedgwick, W. A. (2003). Effective behaviors of expert rowing coaches: A qualitative investigation of Canadian athletes and coaches. International sports journal, $7(1), 62$.

[7] Gould, D., \& Carson, S. (2010). The relationship between perceived coaching behaviors and developmental benefits of high school sports participation. Hellenic journal of psychology, 7(1), 298-314

[8] Gül, M., Türkmen, M., \& Ağaoğlu, S. A. (2015). The Analysis of Wrestling Coaches' Behavior towards Their Athletes in Turkey. International Journal of Wrestling Science, 5(2), 75-78.

[9] Horn TS. Coaching effectiveness in the sport domain. In T.S. Horn (Ed.), Advances in Sport Psychology (1st ed.), 2002; 309-354.

[10] İkizler, H. C. (2000). Sporda sosyal bilimler. Alfa Yayınları, İstanbul

[11] Koh, K. T., Kawabata, M., \& Mallett, C. J. (2014). The coaching behavior scale for sport: Factor structure examination for Singaporean youth athletes. International Journal of Sports Science \& Coaching, 9(6), 1311-1324.

[12] Konter, E. (1996). Bir lider olarak antrenör. Alfa Basım Yayım Dağıtım, İstanbul

[13] Lyle, J. W. B. (1993). Towards a comparative study of the coaching process. Journal of Comparative Physical Education and Sport, 15(2), 14-23.

[14] Serpa, S. O. D. C. (1999). Relationship coach-athlete: outstanding trends in European research. Motricidade humana: portuguese journal of human performances studies, 7-19.

[15] Vargas-Tonsing, T. M., Warners, A. L., \& Feltz, D. L. (2003). The predictability of coaching efficacy on team efficacy and player efficacy in volleyball. Journal of sport 
behavior, 26(4), 396-407.

[16] http://www.gazetepusula.net/2018/01/22/palandokende-sno wboard-sov/

[17] Erişim Taihi: 26.03.2018. 